\title{
Development for Sustainable Construction System Glass Fiber Reinforced Gypsum (GFRG) in Egypt Using Nanotechnology
}

\author{
Mohamed Said Meselhy EISaeed \\ Department of Architecture, Faculty of Engineering, Fayoum University, Fayoum, Egypt \\ Email address: \\ Dr.meselhy@waveegypt.com

\section{To cite this article:} \\ Mohamed Said Meselhy ElSaeed. Development for Sustainable Construction System Glass Fiber Reinforced Gypsum (GFRG) in Egypt \\ Using Nanotechnology. American Journal of Environmental Protection. Vol. 5, No. 4, 2016, pp. 82-89. doi: 10.11648/j.ajep.20160504.12
}

Received: June 7, 2016; Accepted: June 18, 2016; Published: June 30, 2016

\begin{abstract}
One of the mile stones for the success of construction projects is the project management triangle (time, cost and quality). During the past decade, a lot of construction systems have been developed to this triangle. GFRG system was one of these systems (for example that was established in Australia), it fulfilled LEED certificate for construction materials. When it is compared with traditional systems in Egypt, Glass Fiber Reinforced Gypsum (GFRG) system superior to traditional systems in time, cost in case of repetitive projects and quality. The world awareness for sustainability have increased lately in different aspects, thermal comfort is one of the main sustainable aspects that influence users. This paper aims to study thermal comfort for GFRG system in Egypt and comparing with traditional systems, it also aims to study the nanotechnology to develop this construction material in order to increase thermal comfort performance.
\end{abstract}

Keywords: Aerogel, Nanotechnology, GFRG, Thermal Comfort, Egypt

\section{GFRG Definition}

GFRG is the abbreviation for glass fiber reinforced gypsum. It is the name of a new building panel product, made essentially of gypsum plaster, reinforced with glass fibers, and is also known in the industry as GFRG [2]. This product, suitable for rapid mass-scale building construction, was originally developed and used since 1990 in Australia. GFRG is of particular relevance to India, where there is a tremendous need for cost-effective mass-scale affordable housing, and where gypsum is abundantly available as an industrial by-product waste. The product is not only ecofriendly or green, but also resistant to water and fire. GFRG panels are presently manufactured to a thickness of $124 \mathrm{~mm}$, a length of $12 \mathrm{~m}$ and a height of $3 \mathrm{~m}$, under carefully controlled conditions. The panel can be cut to required size [3]. Although its main application is in the construction of walls, it can also be used in floor and roof slabs in combination with reinforced concrete. The panel contains cavities that may be filled with concrete and reinforced with steel bars to impart additional strength and provide ductility. The panels may be unfilled, partially filled or fully filled with reinforced concrete as per structural requirement.

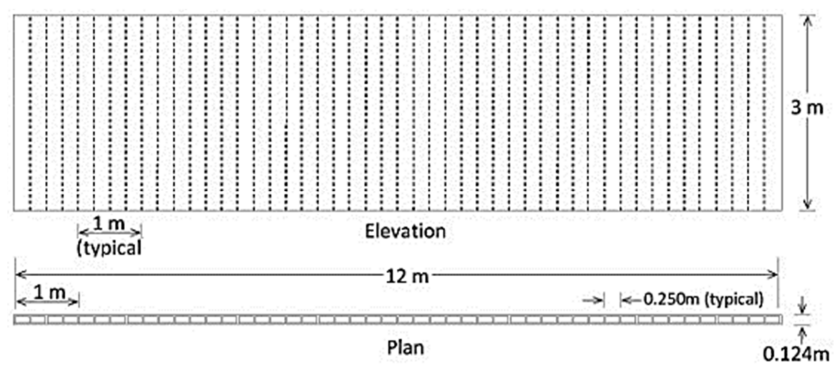

Source: GFRG/Rapidwall Building Structural Design Manual

Figure 1. Typical Cross Section of GFRG Panel.

GFRG building panels are presently manufactured as GFRG, for the typical dimensions and material properties described in the manual. Typical dimensions of a GFRG building panel are $12.0 \mathrm{~m} * 3.0 \mathrm{~m} * 0.124 \mathrm{~m}$, as shown in Fig. 1. Each $1.0 \mathrm{~m}$ segment of the panel contains four 'cells'. Each cell is $250 \mathrm{~mm}$ wide and $124 \mathrm{~mm}$ thick, containing a cavity $230 \mathrm{~mm} * 94 \mathrm{~mm}$, as shown in Fig. 2. The various cells are inter-connected by solid 'ribs' $(20 \mathrm{~mm}$ thick $)$ and 
'flanges' (15 mm thick), comprising gypsum plaster, reinforced with $300-350 \mathrm{~mm}$ glass fiber roving [10], located randomly but centrally. The skin thickness is $15 \mathrm{~mm}$ and rib thickness is $20 \mathrm{~mm}$.

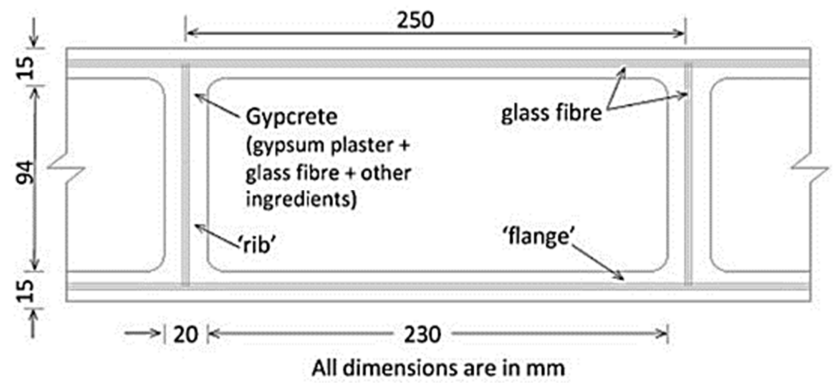

Source: GFRG/Rapidwall Building Structural Design Manual

Figure 2. Enlarged View of a Typical Cell.

\section{GFRG Uses}

In typical multistoried constructions involving the use of GFRG as load bearing structural walling, the connections between cross walls and with the foundations and floor/roof are achieved through reinforced concrete filling or $\mathrm{R}$. C beams. All GFRG wall panels at the ground floor are to be erected over a network of RC plinth beams supported on suitable foundation [6].

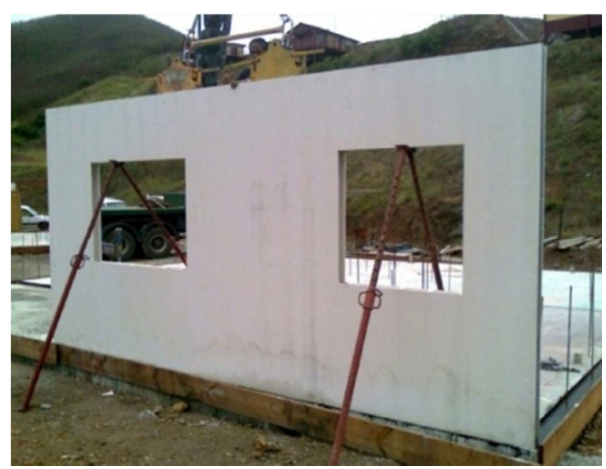

Figure 3. Erection of GFRG panels over plinth beam at site [9].

GFRG panel can also be used for intermediate floor slab/roof slab in combination with RC. The strength of GFRG slabs can be significantly enhanced by embedding reinforced concrete micro beams. For providing embedded micro beams, top flange of the respective cavity is cut and removed in such a way that minimum $25 \mathrm{~mm}$ flange on both end is protruded. RC concrete screed of minimum $50 \mathrm{~mm}$ thickness is provided above the GFRG floor panel, which is reinforced with weld mesh of minimum size of 10 gauge 100 $\mathrm{mm} \times 100 \mathrm{~mm}$ [7]. This RC screed and micro beam act together as series of embedded T-beams. The thickness of the $\mathrm{RC}$ screed, reinforcement and interval of embedded RC micro beams depends on the span and intensity of imposed load. The connectivity between the horizontal tie beam, embedded RC micro beams, concrete screed and vertical rods in GFRG wall, and ensures perfect connection between floor/roof slab and walling system [5].

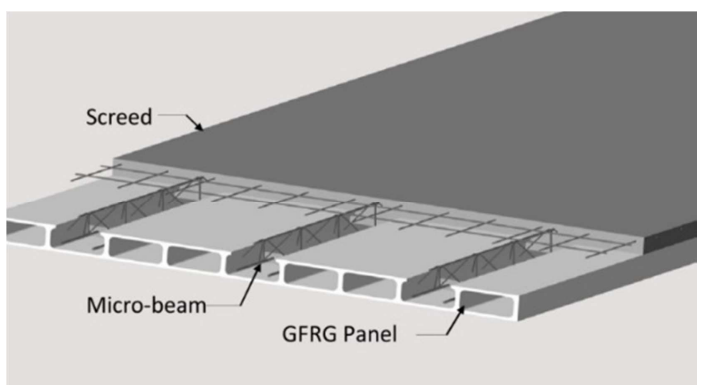

Figure 4. GFRG floor slab with micro beam and screed Installation [8].

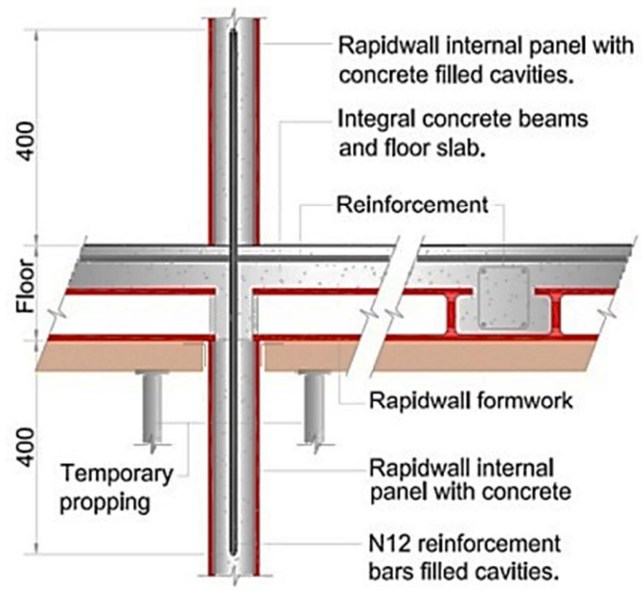

Figure 5. GFRG Floor.

\section{GFRG Projects}

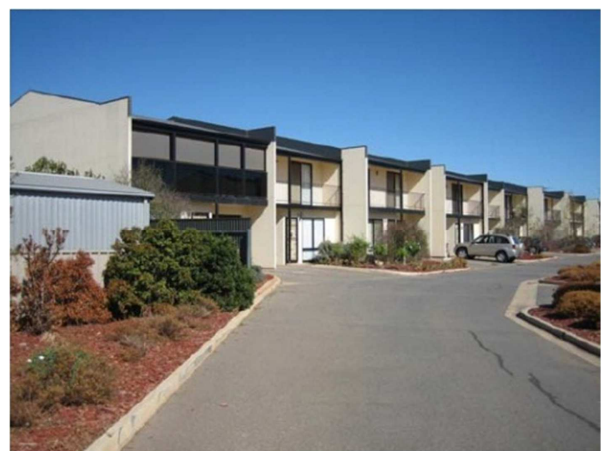

Figure 6. Apartments, Parafield Gardens S. A, Australia Completed November 2002, $2350 M^{2}$ External and Internal Load bearing Rapidwall [14].

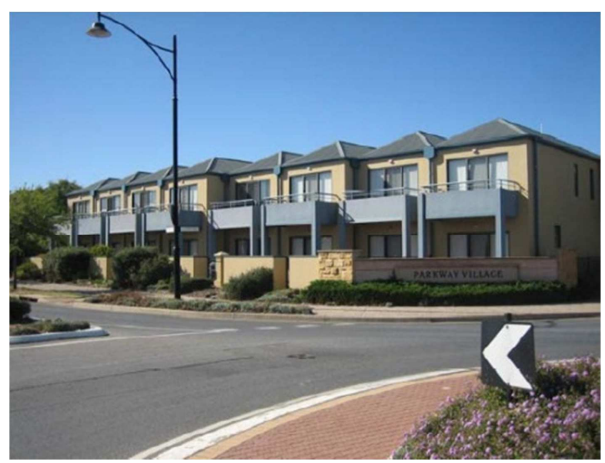

Figure 7. Apartments, Mawson Lakes S. A., Australia. Completed September 2004, $6709 M^{2}$ load bearing Rapidwall [14]. 


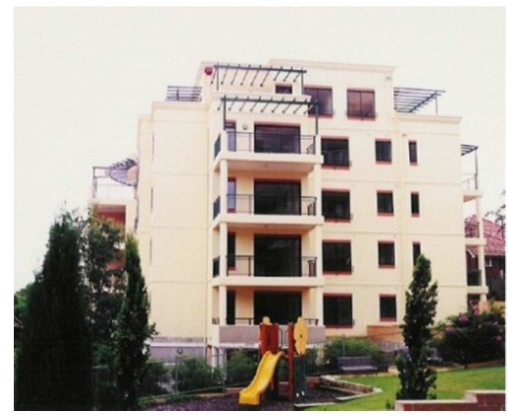

Figure 8. Apartment Residences, West Beach S. A., Australia. Completed November 2005, $910 \mathrm{M}^{2}$ Load bearing external and internal Rapidwall [14].

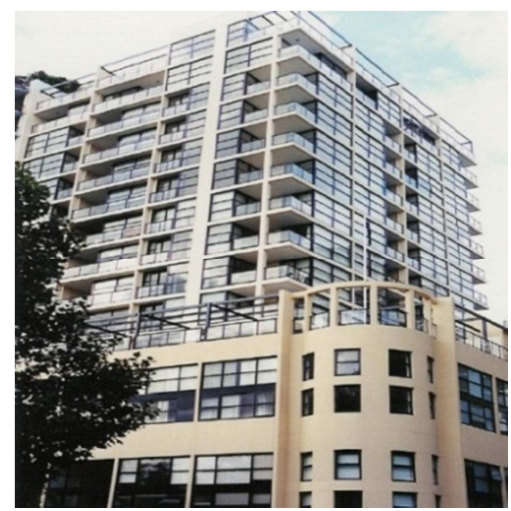

Figure 9. Holliday Housing, New Caledonia Completed March 2009, 3800 $M^{2}$ Load bearing external \& internal Rapid wall [14].

\section{Thermal Comparison Between Traditional Work and GFRG}

Traditional system is meant to be masonry work (Hollow brick units) in addition to concrete slabs, covered with plaster (Cement plaster). The dimensions for bricks and plaster will be considered as schedule below. This paper will study thermal performance for different cases for traditional system as schedule below, using the following U-Value equations. This study was applied upon base model using software "Design Builder"; the dimension for this base model is $3 \mathrm{~m}$ width, $3 \mathrm{~m}$ length and $3 \mathrm{~m}$ height.

\subsection{U-Value Calculations}

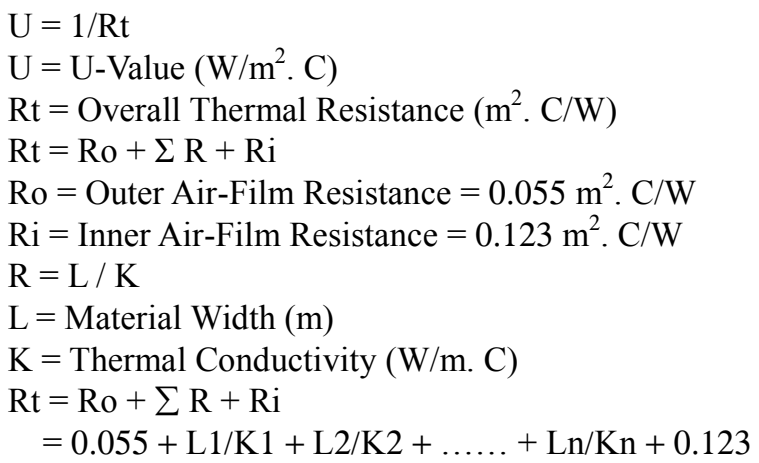

Table 1. U-Value Analysis for Traditional systems (12 mm), $(25 \mathrm{~mm}) \& G F R G$.

\begin{tabular}{|c|c|c|c|c|c|c|}
\hline Wall & Material Layers & $\mathbf{L}(\mathbf{m})$ & $\mathbf{K}(\mathbf{W} / \mathbf{m} . \mathbf{C})$ & $R=L / K$ & $\operatorname{Rt}\left(\mathrm{m}^{2} \cdot \mathrm{C} / \mathrm{W}\right)$ & U-Value (W/m². C) \\
\hline \multirow{5}{*}{ Traditional System $(12 \mathrm{~cm})$} & Outer air-film & & & 0.055 & \multirow{5}{*}{0.42} & \multirow{5}{*}{2.38} \\
\hline & Cement plaster & 0.02 & 0.95 & 0.021 & & \\
\hline & Hollow brick units & 0.12 & 0.60 & 0.20 & & \\
\hline & Cement plaster & 0.02 & 0.95 & 0.021 & & \\
\hline & Inner air-film & & & 0.123 & & \\
\hline \multirow{5}{*}{ Traditional System $(25 \mathrm{~cm})$} & Outer air-film & & & 0.055 & \multirow{5}{*}{0.636} & \multirow{5}{*}{1.57} \\
\hline & Cement plaster & 0.02 & 0.95 & 0.021 & & \\
\hline & Hollow brick units & 0.25 & 0.60 & 0.416 & & \\
\hline & Cement plaster & 0.02 & 0.95 & 0.021 & & \\
\hline & Inner air-film & & & 0.123 & & \\
\hline \multirow{5}{*}{ GFRG System } & Outer air-film & & & 0.055 & \multirow{5}{*}{0.312} & \multirow{5}{*}{3.20} \\
\hline & Gypsum plaster & 0.0145 & 0.42 & 0.0345 & & \\
\hline & Concrete & 0.094 & 1.44 & 0.065 & & \\
\hline & Gypsum plaster & 0.0145 & 0.42 & 0.0345 & & \\
\hline & Inner air-film & & & 0.123 & & \\
\hline
\end{tabular}

Table 2. Annual Thermal comfort analysis for Traditional system (12 mm).

\begin{tabular}{|c|c|c|c|c|c|}
\hline & Mor & & Discon & & Comfort \\
\hline & & & Hot & Cold & Comfort \\
\hline & 1 & January & $0 \%$ & $35 \%$ & $65 \%$ \\
\hline & 2 & February & $22 \%$ & $11 \%$ & $67 \%$ \\
\hline & 3 & March & $39 \%$ & $4 \%$ & $57 \%$ \\
\hline & 4 & April & $67 \%$ & $0 \%$ & $33 \%$ \\
\hline & 5 & May & $95 \%$ & $0 \%$ & $5 \%$ \\
\hline Wall 1 & 6 & June & $100 \%$ & $0 \%$ & $0 \%$ \\
\hline & 7 & July & $100 \%$ & $0 \%$ & $0 \%$ \\
\hline & 8 & August & $100 \%$ & $0 \%$ & $0 \%$ \\
\hline & 9 & September & $100 \%$ & $0 \%$ & $0 \%$ \\
\hline & 10 & October & $100 \%$ & $0 \%$ & $0 \%$ \\
\hline & 11 & November & $67 \%$ & $8 \%$ & $25 \%$ \\
\hline & 12 & December & $21 \%$ & $10 \%$ & $69 \%$ \\
\hline
\end{tabular}




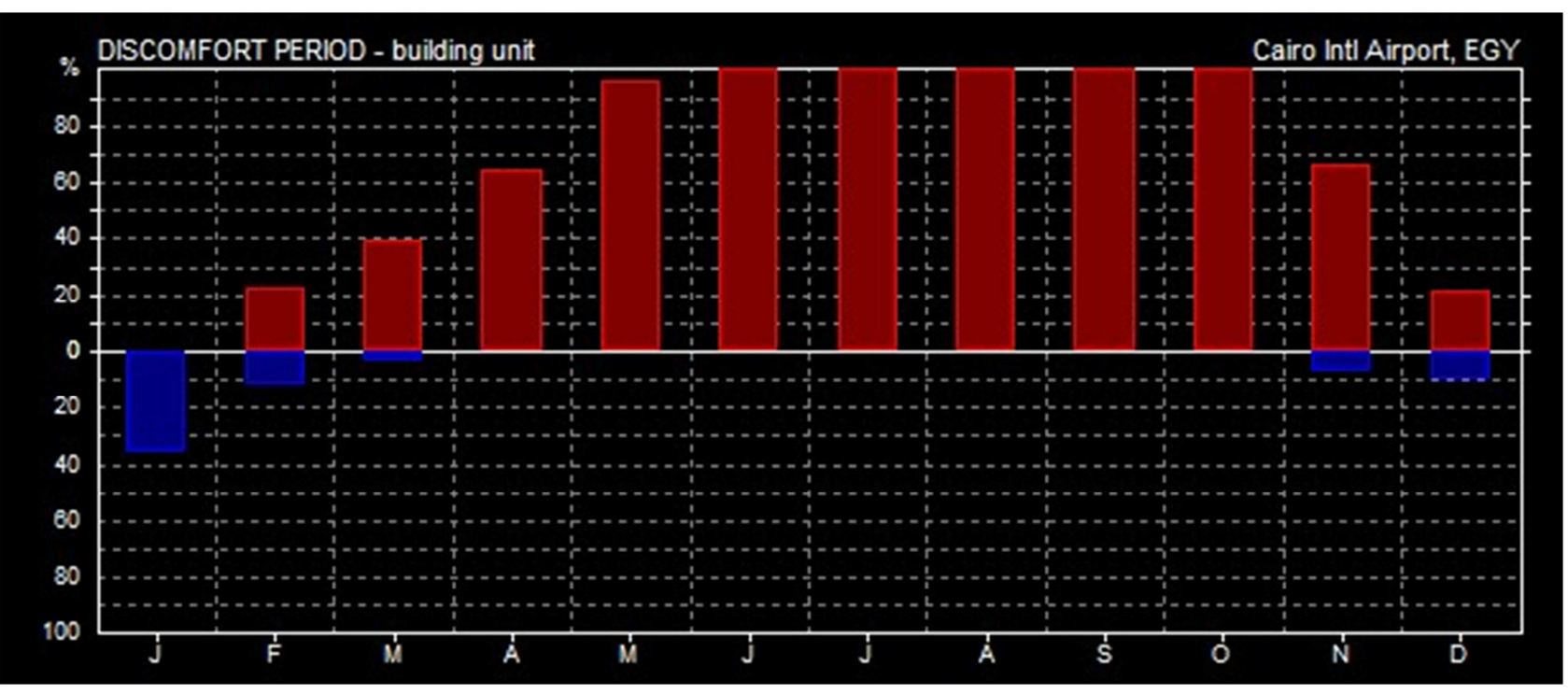

Figure 10. Annual Thermal comfort analysis Traditional System $(12 \mathrm{~cm})$.

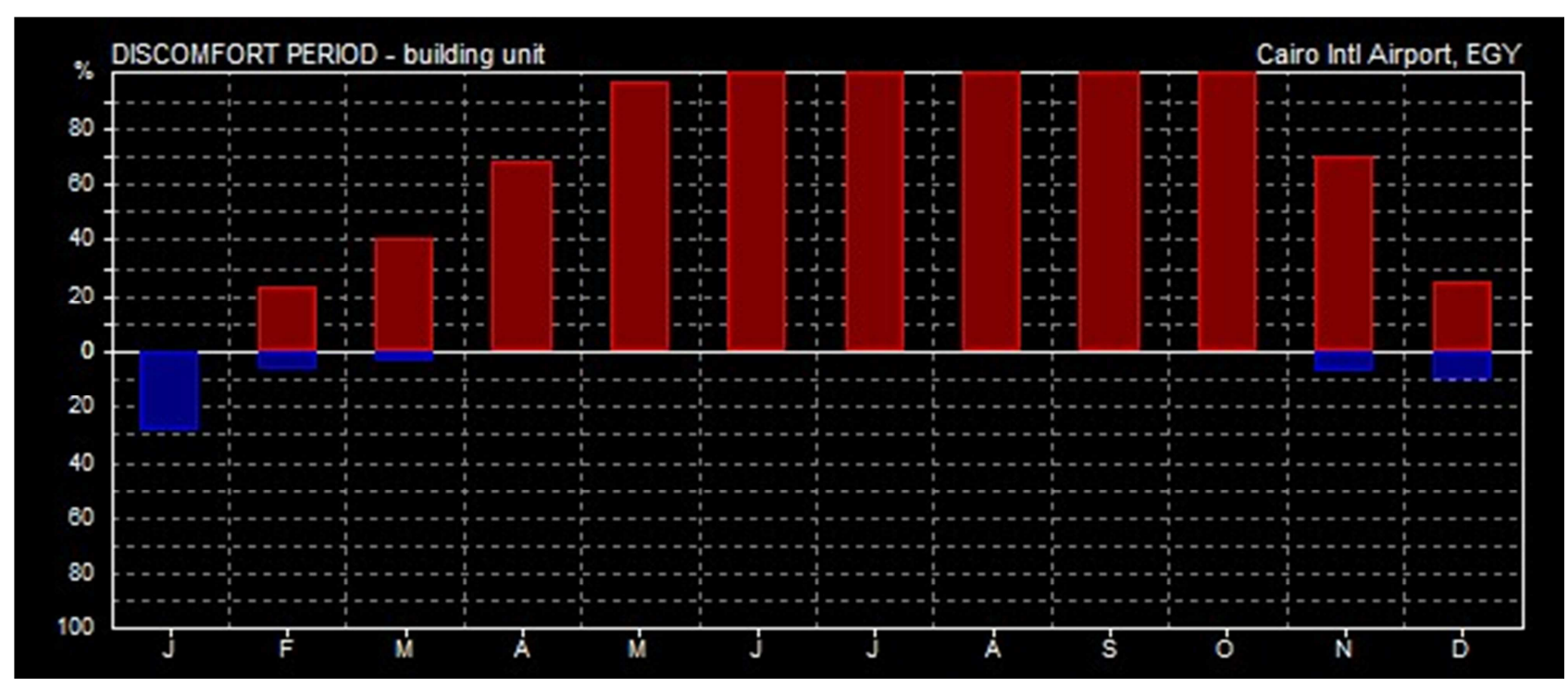

Figure 11. Annual Thermal comfort analysis Traditional System $(25 \mathrm{~cm})$.

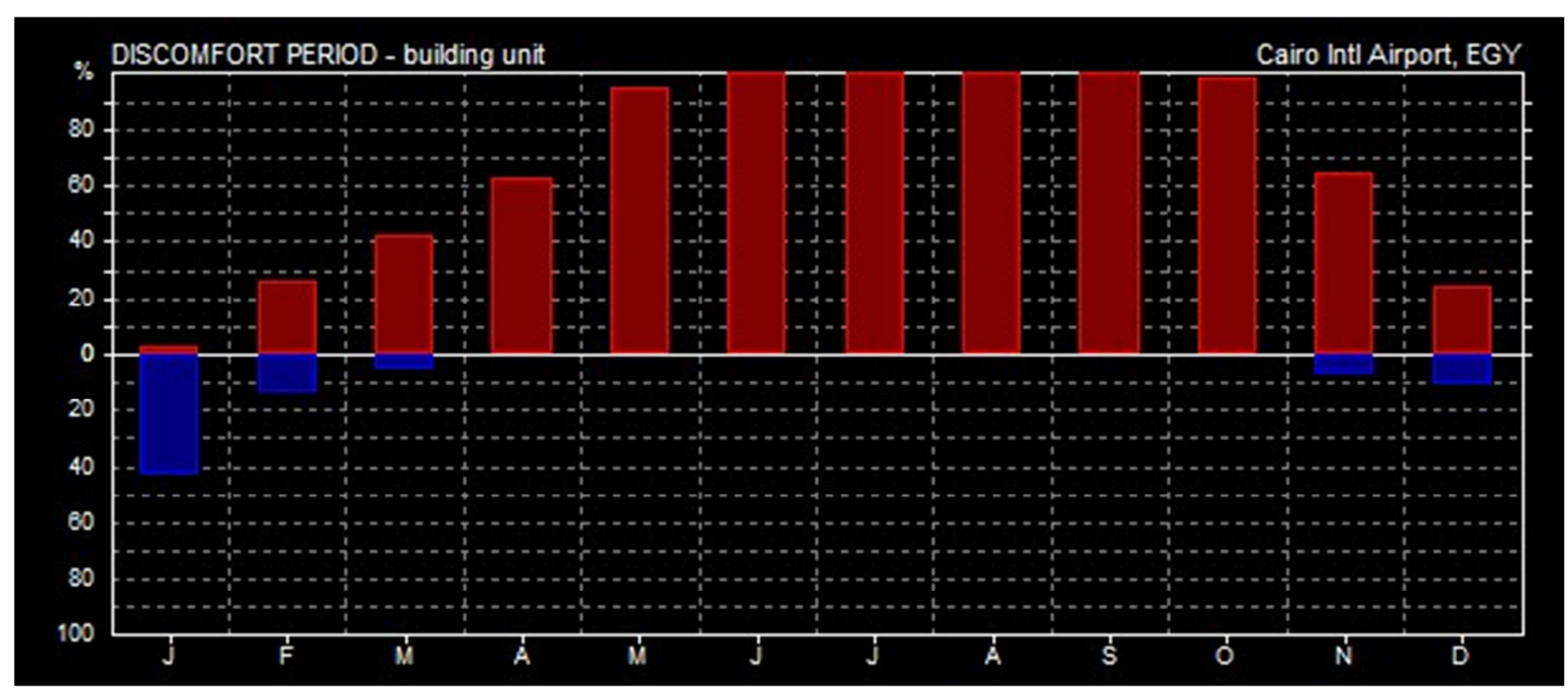

Figure 12. Annual Thermal comfort analysis GFRG system. 


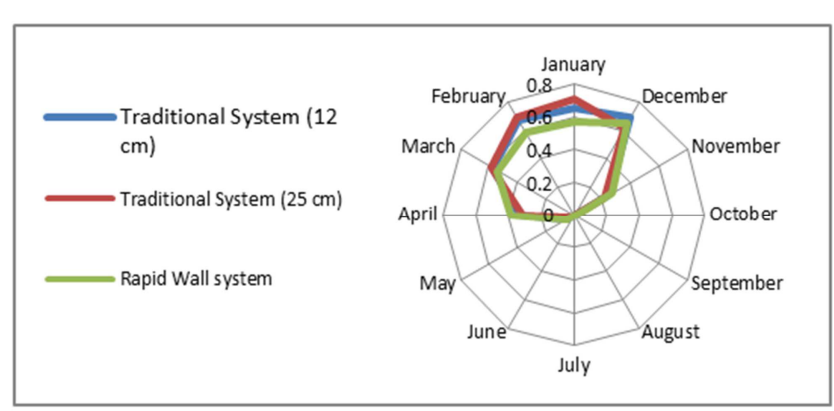

Figure 13. Thermal Comfort Analysis.

Figure 13 shows that there is no remarkable difference between different systems studied above, so it is required to have additional input to have remarkable impact upon thermal comfort zone for the base model.

Table 3. Annual Thermal comfort analysis for Traditional system $(25 \mathrm{~mm})$.

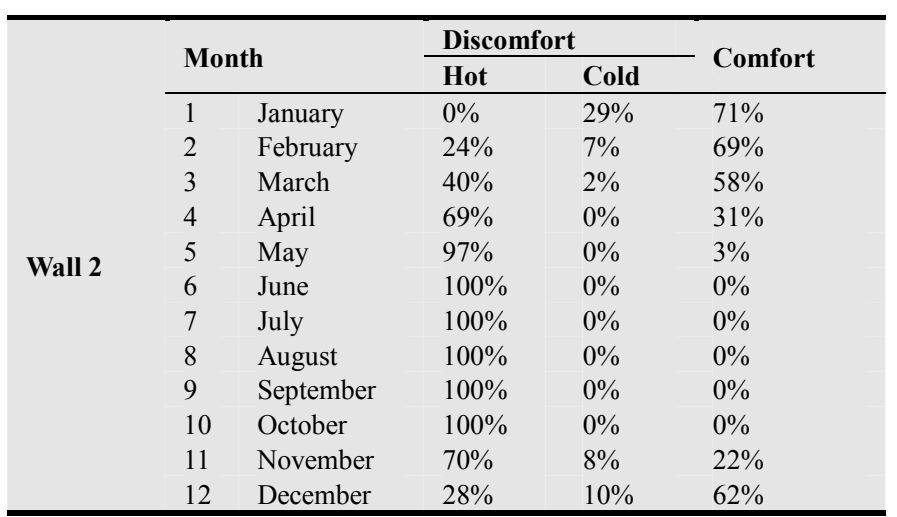

Table 4. Annual Thermal comfort analysis GFRG system.

\begin{tabular}{|c|c|c|c|c|c|}
\hline \multirow{14}{*}{ Wall 3} & \multirow{2}{*}{\multicolumn{2}{|c|}{ Month }} & \multicolumn{2}{|c|}{ Discomfort } & \multirow{2}{*}{ Comfort } \\
\hline & & & Hot & Cold & \\
\hline & 1 & January & $2 \%$ & $41 \%$ & $57 \%$ \\
\hline & 2 & February & $28 \%$ & $14 \%$ & $58 \%$ \\
\hline & 3 & March & $41 \%$ & $5 \%$ & $54 \%$ \\
\hline & 4 & April & $62 \%$ & $0 \%$ & $38 \%$ \\
\hline & 5 & May & $95 \%$ & $0 \%$ & $5 \%$ \\
\hline & 6 & June & $100 \%$ & $0 \%$ & $0 \%$ \\
\hline & 7 & July & $100 \%$ & $0 \%$ & $0 \%$ \\
\hline & 8 & August & $100 \%$ & $0 \%$ & $0 \%$ \\
\hline & 9 & September & $100 \%$ & $0 \%$ & $0 \%$ \\
\hline & 10 & October & $99 \%$ & $0 \%$ & $1 \%$ \\
\hline & 11 & November & $65 \%$ & $8 \%$ & $27 \%$ \\
\hline & 12 & December & $25 \%$ & $10 \%$ & $65 \%$ \\
\hline
\end{tabular}

\subsection{Nanotechnology in Construction}

Nanotechnology and nanomaterials offer interesting new opportunities in the construction industry and architecture, for example through the development of very durable, longlived and at the same time extremely lightweight construction materials. Novel insulation materials with very good insulation values are already available on the market, enable a thermal rehabilitation of buildings in which conventional insulation is not possible, and can help to improve energy efficiency [11]. A wide range of methods for the treatment of surfaces is also available, including glass, masonry, wood or metal; the goal is to improve functionalities as well as extend the lifetime of the materials. Such surface coatings also promise to conserve resources, for example water, energy and cleaning agents. Although the research sector has been reporting intensively about new Nano-technological developments, the reality shows that "Nano-products" in the construction industry continue to play a subordinate role and currently merely occupy niche markets. The construction business is considered to be conservative, and innovations often have a difficult time breaking into the market. One of the main reasons for this is the continued high prices. Currently, nanomaterials - and therefore "Nano-products" are still considerably more expensive than the conventional alternatives due to the required production technology. Construction materials are generally used in large amounts: small price differences can enormously increase overall costs when considering the total volume of a building or other structure. Moreover, the technical performance of new products must first be demonstrated. In buildings, the calculated time spans are in the range of 20 to 30 years, making it difficult for example to apply a coating with a durability of only 1 to 3 years [12]. Longer-term, practical experience with many Nano-products is still lacking, and we simply know too little about their product life. Accordingly, the construction industry for the time being prefers to rely on proven, conventional products. Nano-technological applications and products, their availability and their performance in the construction industry are currently very limited. A survey conducted in 2009 in the European construction sector showed that most respondents $(\sim 75 \%)$ were unaware of whether they were working with "Nanoproducts" or not. This is also partly because there is no mandatory labeling of nanomaterials in building materials: the prefix "Nano" - like in many other branches - is used in advertising a product only if the manufacturers have justified hopes of improved sales. Often, it is not evident to users whether a Nano-product actually contains nanomaterials, what nanomaterials might be involved and in what amounts they may be present. Not all products that feature the term "Nano" actually contain nanomaterials. Often, the term "Nano" merely refers to structures in the Nano size range, for example the pore size of a particular material, or to the size of structures that form when a mortar hardens. The use of the designation "Nano" in product claims and advertising has again been declining in recent years [12].

\subsection{Aerogel Nanomaterials}

Nano technology materials are now have great impact upon construction and design phase, Aerogel is considered one of the nanotechnology materials that participated in construction industry. Aerogels are highly porous solid materials which can consist of $99 \%$ air [1]. Aerogel is an excellent hypervelocity space debris capture medium due to the fact that it is a highly porous material with a tortuous microstructure made up of Nano-scale particles forming aggregates. [13]. Comparable to an ultra-fine sponge, this 
miracle material has its origin - like many other inventions in space technology. As highly efficient insulators and extremely fine filters, aerogels have made important contributions to space research for years. Aerogel material can be used as aerogel tiles and aerogel granulate [4].

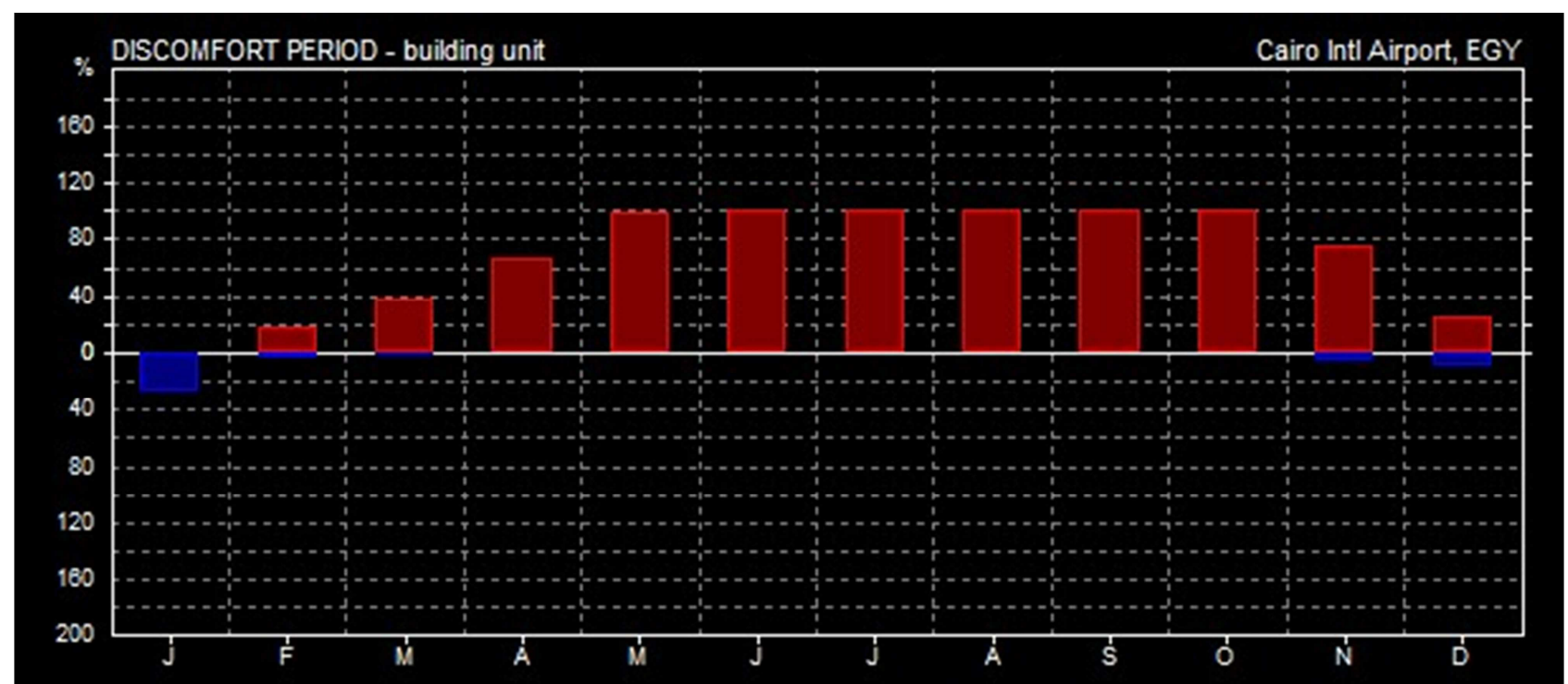

Figure 14. Annual Thermal comfort analysis GFRG system after Aerogel tiles.

Table 5. U-Value Analysis for GFRG system after adding Aerogel tiles and Aerogel Granulate.

\begin{tabular}{|c|c|c|c|c|c|c|}
\hline Wall & Material Layers & $\mathbf{L}(\mathbf{m})$ & $\mathbf{K}(\mathbf{W} / \mathbf{m} . \mathbf{C})$ & $\mathbf{R}=\mathbf{L} / \mathbf{K}$ & $\operatorname{Rt}\left(\mathrm{m}^{2} . \mathrm{C} / \mathrm{W}\right)$ & U-Value $\left(\mathrm{W} / \mathrm{m}^{2} . \mathrm{C}\right)$ \\
\hline \multirow{6}{*}{ Aerogel tiles } & Outer air-film & & & 0.055 & \multirow{6}{*}{0.65} & \multirow{6}{*}{1.522} \\
\hline & Aerogel tiles & 0.0254 & 0.021 & 1.21 & & \\
\hline & Gypsum plaster & 0.0145 & 0.42 & 0.0345 & & \\
\hline & Concrete & 0.094 & 1.44 & 0.065 & & \\
\hline & Gypsum plaster & 0.0145 & 0.42 & 0.0345 & & \\
\hline & Inner air-film & & & 0.123 & & \\
\hline \multirow{6}{*}{ Aerogel granulate } & Outer air-film & & & 0.055 & \multirow{6}{*}{0.532} & \multirow{6}{*}{1.87} \\
\hline & Aerogel granulate & 0.004 & 0.018 & 0.22 & & \\
\hline & Gypsum plaster & 0.0145 & 0.42 & 0.0345 & & \\
\hline & Concrete & 0.094 & 1.44 & 0.065 & & \\
\hline & Gypsum plaster & 0.0145 & 0.42 & 0.0345 & & \\
\hline & Inner air-film & & & 0.123 & & \\
\hline
\end{tabular}

Table 6. Annual Thermal comfort analysis GFRG system after Aerogel tiles.

\begin{tabular}{|c|c|c|c|c|c|}
\hline \multirow{14}{*}{ Wall 4} & \multirow{2}{*}{\multicolumn{2}{|c|}{ Month }} & \multicolumn{2}{|c|}{ Discomfort } & \multirow{3}{*}{$\begin{array}{l}\text { Comfort } \\
72 \%\end{array}$} \\
\hline & & & Hot & Cold & \\
\hline & 1 & January & $0 \%$ & $28 \%$ & \\
\hline & 2 & February & $19 \%$ & $1 \%$ & $80 \%$ \\
\hline & 3 & March & $39 \%$ & $1 \%$ & $60 \%$ \\
\hline & 4 & April & $64 \%$ & $0 \%$ & $36 \%$ \\
\hline & 5 & May & $94 \%$ & $0 \%$ & $6 \%$ \\
\hline & 6 & June & $100 \%$ & $0 \%$ & $0 \%$ \\
\hline & 7 & July & $100 \%$ & $0 \%$ & $0 \%$ \\
\hline & 8 & August & $100 \%$ & $0 \%$ & $0 \%$ \\
\hline & 9 & September & $100 \%$ & $0 \%$ & $0 \%$ \\
\hline & 10 & October & $100 \%$ & $0 \%$ & $0 \%$ \\
\hline & 11 & November & $75 \%$ & $4 \%$ & $21 \%$ \\
\hline & 12 & December & $22 \%$ & $8 \%$ & $70 \%$ \\
\hline
\end{tabular}


Table 7. Annual Thermal comfort analysis GFRG system after Aerogel Granulate.

\begin{tabular}{|c|c|c|c|c|c|}
\hline \multirow{14}{*}{ Wall 4} & \multirow{2}{*}{\multicolumn{2}{|c|}{ Month }} & \multicolumn{2}{|c|}{ Discomfort } & \multirow{2}{*}{ Comfort } \\
\hline & & & Hot & Cold & \\
\hline & 1 & January & $0 \%$ & $35 \%$ & $65 \%$ \\
\hline & 2 & February & $15 \%$ & $5 \%$ & $74 \%$ \\
\hline & 3 & March & $34 \%$ & $0 \%$ & $61 \%$ \\
\hline & 4 & April & $58 \%$ & $0 \%$ & $42 \%$ \\
\hline & 5 & May & $94 \%$ & $0 \%$ & $6 \%$ \\
\hline & 6 & June & $100 \%$ & $0 \%$ & $0 \%$ \\
\hline & 7 & July & $100 \%$ & $0 \%$ & $0 \%$ \\
\hline & 8 & August & $100 \%$ & $0 \%$ & $0 \%$ \\
\hline & 9 & September & $100 \%$ & $0 \%$ & $0 \%$ \\
\hline & 10 & October & $100 \%$ & $0 \%$ & $0 \%$ \\
\hline & 11 & November & $63 \%$ & $8 \%$ & $29 \%$ \\
\hline & 12 & December & $16 \%$ & $118 \%$ & $73 \%$ \\
\hline
\end{tabular}

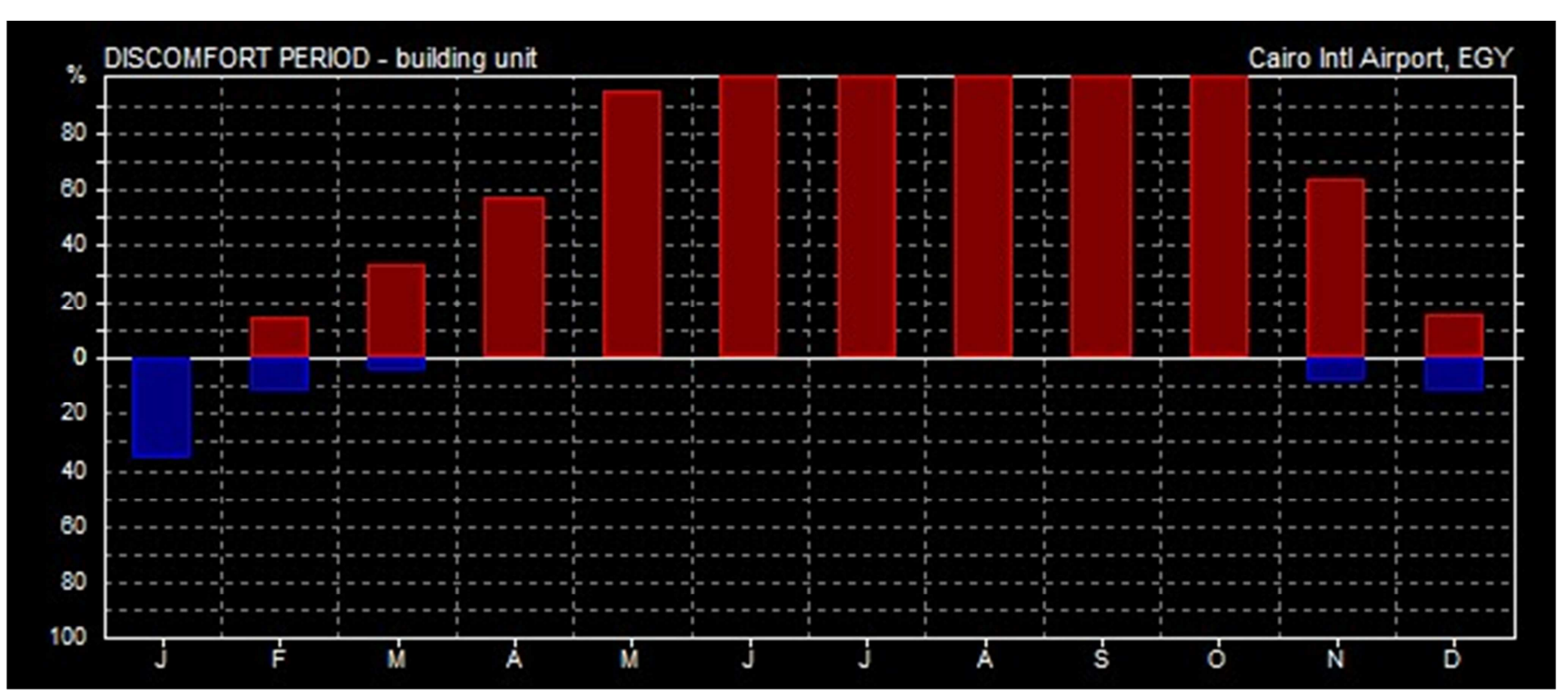

Figure 15. Annual Thermal comfort analysis GFRG system after Aerogel Granulate.

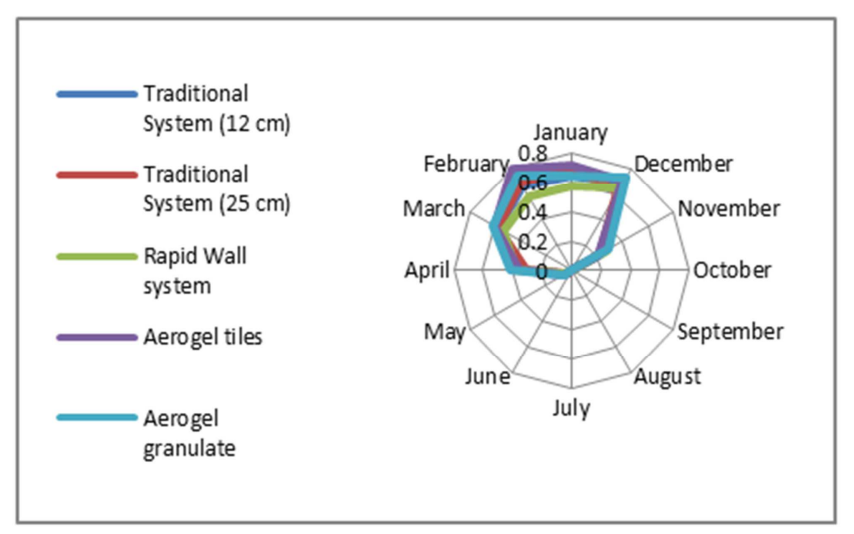

Figure 16. Thermal Comfort Performance.

\section{Conclusion}

1. After adding aerogel materials (tiles and granulate), the thermal comfort performance is slightly improved during the period from November to April. This improvement was below our expectations for thermal comfort performance.
2. When we compared traditional system with GFRG system, the thermal comfort performance was almost the same;

3. Thermal conductivity factor in GFRG was higher than expected due to filling of concrete to the cavity of GFRG system in external walls especially.

4. Structural analysis need to be considered in next studies in this field, in order to minimize the usage of concrete filling in different walls in GFRG system.

5. Despite the usage of nanotechnology materials to adapt thermal comfort performance for materials, we must not ignore the sustainable treatments for thermal comfort.

\section{References}

[1] Aerogel brochure, HECK Wall Systems GmbH \& Co. KG, Tholauer Strabe 25, 95615 Marktredwitz, Germany.

[2] GFRG/RAPIDWALL BUILDING, STRUCTURAL DESIGN MANUAL, Building Materials \& Technology Promotion Council, Ministry of Housing \& Urban Poverty Alleviation, Government of India, December 2011. 
[3] Rapidwall installation manual, Building Materials \& Technology Promotion Council, Ministry of Housing \& Urban Poverty Alleviation, Government of India, December 2011.

[4] Energy Efficient Sustainable Construction - AEROGELS Super insulating Building Materials, TECNALIA, Parque Científico y Tecnológico de Bizkaia C/ Geldo, Edificio 700.

[5] IIT Madras, GFRG Building, Structural Design Manual, Building Materials \& Technology Promotion Council, Ministry of Housing \& Urban Poverty Alleviation, Government of India, 2011.

[6] GFRG, Engineering Design Guidelines, compiled by Ms Dare Sutton Clarke Engineers, Adelaide, Australia, 2002.

[7] Serc, Evaluation of seismic performance of gypcrete building panels, Structural Engineering Research Centre, Chennai, India, 2002

[8] Wu, Y. F., the effect of longitudinal reinforcement on the cyclic shear behavior of glass fiber reinforced gypsum wall panels: tests. Engineering Structures, 26 (11): 1633-46, 2004.
[9] $\mathrm{Wu}, \mathrm{Y} . \mathrm{F}$., the structural behavior and design methodology for a new building system consisting of glass fiber reinforced gypsum panels, Construction and Building Materials, Volume 23, 2905-2913, 2009.

[10] IITM, Material properties and assessment of gypcrete building panels, Indian Institute of Technology, Madras, India; September 2002. Project no. CE/BTCM/2557/2002, 2002.

[11] Leydecker, Sylvia, Nanomaterialien in Architektur, Innenarchitektur und Design: Birkhäuser Verlag, 2008.

[12] Van Broekhuizen, Fleur/Van Broekhuizen, Pieter, Nanoprodukte im europäischen Baugewerbe - Aktueller Sachstand 2009.

[13] Woignier T., Duffours L., Colombel P, and Durin C., Aerogels Materials as Space Debris Collectors, Hindawi Publishing Corporation Advances in Materials Science and Engineering Volume 2013, Article ID 484153, 2013.

[14] Rapidwall Projects list, Materials \& Technology Promotion Council, Ministry of Housing \& Urban Poverty Alleviation, Government of India, 2009. 